\title{
Heat Stress in Residential Buildings as a Result of Deficient HVAC Systems
}

\author{
Mayuri Rajput ${ }^{1}$, Godfried Augenbroe ${ }^{1}$ \\ ${ }^{1}$ Georgia Institute of Technology, Atlanta, USA
}

\begin{abstract}
This study assesses the problem of overheating in vintage (generally older than 10 years) residential buildings of low-income households in Atlanta, which are prone to overheating not only due to poor envelope properties but also for the reason that air conditioners do not operate at the capacity which would result in insufficient cooling of space. These are the cases where either the air conditioner is not maintained over the years or they are under-sized for sultry days. The objective of this paper is to simulate the behavior of residences with deficient HVAC. Typical single-family detached residences are simulated for both TMY as well as HMY as weather inputs. The simulation models the scenarios where air conditioner capacities are varied from 1 (aptly sized system) to 0 (a dysfunctional air conditioner) to obtain indoor environmental temperatures. These are then used in comfort and stress measures that represent physiological thermal stress in these dwellings. The investigation reflects the seriousness of the problem posed by these sub-par air conditioners and the paper concludes with a discussion on the use of TMY vs HMY for such studies.
\end{abstract}

\section{Introduction}

Heat exposure in buildings has been studied for various reasons. Global warming in conjunction with other factors like urbanization and associated heat island effects, lack of thermal mass, exposure to solar insolation on higher stories, absence of window shading, overcrowding and envelope properties exacerbate the overheating inside the dwellings.

Buildings can overheat in such conditions, mostly because of undersized cooling capacity or because the building was deemed to operate without mechanical cooling. The current literature separates the standards of overheating in two groups, namely, naturally cooled buildings (Passivhaus Institut-2012, British standard EN15251 and ASHRAE adaptive standards) and mechanically cooled buildings (ASHRAE 55).

Adaptive standards such as CIBSE (CIBSE Guide C Reference Data - Georgia Tech Library, n.d.)(Masoud, Sameni, Gaterell, Montazami, \& Ahmed, 2015) and EN 15251 rely heavily on the running mean outside temperature and are essentially applicable to free running buildings.

Although much work has been done to assess the risk of overheating in buildings, there is still a lack of convergence and acceptability on the methods employed to account for heat stress as a result of overheating.

The use of TMY is a norm for energy studies in buildings as they are a representation of "average" weather of location. However, its use in resilience and heat risk assessments have been debated in literature for a long time. The use of Historical Meteorological Years (HMY's) in this study from 1974 to 2012 includes the extremities of climate in Atlanta over a considerably long time-span.

There is a variety of human comfort measures and indices that can be used to express human sensation to high temperatures and humidity. A "gap" exists between the indices that are based on the holistic consideration of human physiology including heart rate, rectal temperature and skin conductance verses indices based on no physiological parameters or only a simplified physiological model, for instance of the skin. In that case the indices are either based on purely physical variables of the environment (eg., air and mean radiant temperature) or based on a simple model of the skin temperature.

(Epstein \& Moran, 2006)categorized the indices in three groups namely, rational indices (based on heat balance equations), empirical indices (based on objective and subjective strain) and direct indices (based on measurement of environmental variables). The review paper of (Beshir \& Ramsey, 1988) is a helpful source to compile the list of applicable indices considered in this paper.

The study paves way to design a framework for assessment of heat risk in low income communities of society marred by ill maintained houses and mechanical systems. It would specifically be helpful for future studies in determining the vulnerability of deprived communities and role of environmental-social justice in devising solutions to accelerated warming of the climate that these communities will be affected by the most.

\section{Methodology}

The study has three phases, namely;

1. Determination of construction practices in the city of Atlanta for vintage buildings and their envelope properties.

2. Development of nimble simulation model to efficiently assess many construction variants and 
scenarios of operation (eg, shading, occupancy, availability of mechanical cooling etc).

3. Post processing of environmental conditions for derivation of heat indices.

4. Evaluation of results to ascertain the heat risk due to design conditions, in particular the specification of weather (TMY vs HMY) alongwith a comparison of technique used to quantify heat risk, ie, intensity of different indices for these design conditions.

\section{Building Archetypes}

Assessment of the current building stock may be done through surveys as well as databases offered by government bodies specializing in city and regional planning. Studies such as, (Zhao, Lee, \& Augenbroe, 2016, Lim \& Zhai, 2017 and Zhao et al., 2016) represent ways in which archetypical buildings act as representatives of a city's building stock for energy as well as comfort assessments. To generate the prototypes of residential buildings in the city of Atlanta, we use the generic residential prototypes published by US DOE, Building Energy Codes Program("Residential Prototype Building Models Building Energy Codes Program,” n.d.) as our baseline. Since this study is focused on relative differences between building performance based on type of weather data used as boundary condition and vintage of construction, 2-story detached residence with basement is selected as a representative case to study the effects of weather and the other parameters.

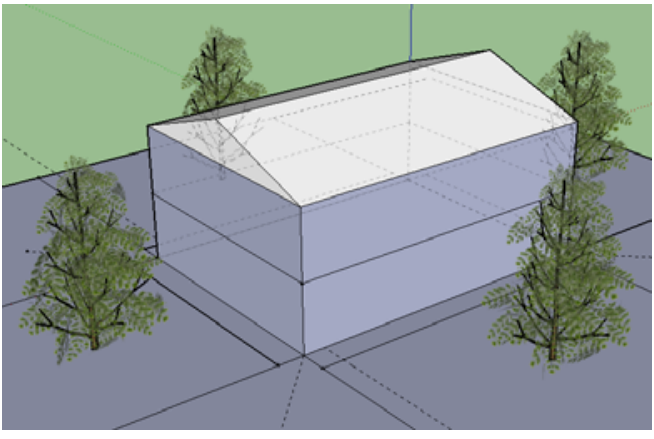

Figure 1. 3D model of representative building

As each side is not significantly different in size, and WWR and U-value are the same on each side with no (external) shading devices, it may be concluded that orientation does not play a significant role in this building prototype.

Two construction variants are used to represent vintage building stock, namely, brick and masonry construction (Shirazi, Environment, \& 2018, n.d.) and construction conforming to IECC 2000 building codes. Table 1 represents the thermal properties of each construction variant.

The use of shading trees in landscaping is expected to reduce the cooling load and glare in the buildings. The presence of trees reduces direct solar gain through windows and reduces surface temperature of facades by radiative shading (direct blocking of solar radiation) with reported reduction of up-to $30 \%$ cooling in HVAC loads
(International Council for Research and Innovation in Building and Construction. \& Akbari, 1977). A shaded variant for each type of construction is simulated to consider the effect of shading on thermal performance of the chosen archetypal building. Redwood Dawn tree 3D models are placed on cardinal directions around the building at 3 meters distance from the wall. Transient shading coefficients for each façade surface are computed using Ecotect for $15^{\text {th }}$ July as the average summer day as far as solar angles are concerned. The calculated shading coefficients are then used for all simulated summer days.

\section{Table 1.Construction properties of building variants}

\begin{tabular}{|c|c|c|c|c|}
\hline \multirow{2}{*}{\multicolumn{5}{|c|}{$\begin{array}{l}\text { Thickness (m) Density }\left(\mathrm{kg} / \mathrm{m}^{3}\right) \text { Specific Heat Capacity (J/kg-C)Thermal conductivity (W/m-C) } \\
\text { Brick-Masonry Construction }\end{array}$}} \\
\hline & & & & \\
\hline \multicolumn{5}{|l|}{ Exterior Wall } \\
\hline Brick & 0.1 & 1920 & 800 & 0.98 \\
\hline Fiberglass insulation & 0.15 & 48 & 800 & 0.048 \\
\hline Air barrier & 0.1 & 1.225 & 1005 & 6.3 \\
\hline Gypsum board & 0.0125 & 1120 & 465 & 0.38 \\
\hline \multicolumn{5}{|l|}{ Basement Wall } \\
\hline Concrete (dense) & 0.15 & 2000 & 960 & 1.13 \\
\hline \multicolumn{5}{|l|}{ Roof } \\
\hline Asphalt Shingle & 0.063 & 1121 & 1255 & 0.081 \\
\hline Fiberglass Batt & 0.12 & 48 & 800 & 0.048 \\
\hline \multicolumn{5}{|l|}{ Attic } \\
\hline Ceiling console layer & 0.21 & 41.92 & 776 & 0.04 \\
\hline Drywall $0.5^{\prime \prime}$ & 0.0127 & 801 & 1087 & 0.16 \\
\hline \multicolumn{5}{|l|}{ Window } \\
\hline Glass (single pane) & 0.01 & 2400 & 1200 & 5.8 \\
\hline \multicolumn{5}{|l|}{ Exterior Floor } \\
\hline Carpet \& Pad & 0.025 & 32 & 836 & 0.06 \\
\hline Plywood 3/4" & 0.019 & 544 & 674 & 0.1154 \\
\hline Floor Console & 0.05 & 55.07 & 916 & 0.048 \\
\hline Soil & 0.8 & 1800 & 920 & 1.1 \\
\hline \multicolumn{5}{|l|}{ Interior Floor } \\
\hline Carpet \& Pad & 0.025 & 32 & 836 & 0.06 \\
\hline Plywood 3/4" & 0.019 & 544 & 674 & 0.1154 \\
\hline \multirow{2}{*}{\multicolumn{5}{|c|}{ Infiltration- 3 Air Changes/hour }} \\
\hline & & & & \\
\hline \multicolumn{5}{|l|}{ Exterior Wall } \\
\hline Stucco & 0.025 & 1922 & 878.6 & 1.39 \\
\hline Sheathing & 0.025 & 685 & 1172 & 0.094 \\
\hline OSB $5 / 8^{\prime \prime}$ & 0.012 & 544.6 & 1213 & 0.1163 \\
\hline Wall console & 0.25 & 120 & 1036.25 & 0.059 \\
\hline Dry Wall & 0.02 & 800 & 1087 & 0.16 \\
\hline \multicolumn{5}{|l|}{ Basement Wall } \\
\hline Concrete (dense) & 0.15 & 2000 & 960 & 1.13 \\
\hline \multicolumn{5}{|l|}{ Roof } \\
\hline Mineral Woool, felted & 0.08 & 30 & 1380 & 0.04 \\
\hline Rock wool board (Roofing) & 0.45 & 160 & 800 & 0.039 \\
\hline \multicolumn{5}{|l|}{ Attic } \\
\hline Ceiling console layer & 0.21 & 41.92 & 776 & 0.04 \\
\hline Drywall $0.5^{\prime \prime}$ & 0.0127 & 801 & 1087 & 0.16 \\
\hline \multicolumn{5}{|l|}{ Window } \\
\hline Glass (double pane with $6 \mathrm{~mm}$ air & 0.01 & 2400 & 1200 & 4 \\
\hline \multicolumn{5}{|l|}{ Exterior Floor } \\
\hline Carpet \& Pad & 0.025 & 32 & 836 & 0.06 \\
\hline Mineral Fiberboard, wet felted & 0.019 & 160 & 800 & 0.037 \\
\hline Expanded Rubber (Rigid) & 0.4 & 64 & 1700 & 0.029 \\
\hline Soil & 0.8 & 1200 & 1100 & 0.7 \\
\hline \multicolumn{5}{|l|}{ Interior Floor } \\
\hline Carpet \& Pad & 0.025 & 32 & 836 & 0.06 \\
\hline Plywood 3/4" & 0.019 & 544 & 674 & 0.1154 \\
\hline
\end{tabular}

\section{Finite-Element MATLAB Model}

Thermal Model: The energy model of the prototype building are developed using a standard finite element spatial discretization technique as discussed in (Augenbroe et al., n.d.) It discretizes the building fabric and internal zones as a mesh of nodes and elements where the nodes represent state variables (temperatures) and the elements represent modes of heat transfer (conduction, convection, radiation and airflow).

A zone node represents the uniform temperature of the air contained in the room which is assumed to be well mixed. Elements connect nodes that exchange some form of energy, while element properties reflect the heat transfer mechanism operating between the respective nodes of the element. Boundary conditions at the external surfaces are modelled as elements that connect surface node to external nodes that contain the given ambient, sky and ground temperature. 


\begin{tabular}{|c|c|c|}
\hline Type of Element & Connection & $\begin{array}{l}\text { Physical factors affecting } \\
\text { element }\end{array}$ \\
\hline Conduction & & $\begin{array}{l}\text { Thermal conductivity }\left(\mathrm{W} / \mathrm{m}^{2} \mathrm{~K}\right) \text {, } \\
\text { Heat transfer area of nodes }\left(\mathrm{m}^{2}\right) \text {. } \\
\text { thickness of element }(\mathrm{m})\end{array}$ \\
\hline Convection & & $\begin{array}{c}\text { Convective heat coefficient } h_{c} \\
\left(W / \mathrm{m}^{2} \mathrm{~K}\right) \text {.Ieat transfer area of } \\
\text { nodes }\left(\mathrm{m}^{2}\right)\end{array}$ \\
\hline Radiation & & $\begin{array}{l}\text { Lincarioed radiative heat transfer } \\
\text { coefficicnt } h_{\text {rad }}\left(\mathrm{W} / \mathrm{m}^{2} \mathrm{~K}\right) \text {, Vicw } \\
\text { factor (dimensionless), Heat } \\
\text { transfer area of nodes }\left(\mathrm{m}^{2}\right)\end{array}$ \\
\hline Airflow & & $\begin{array}{l}\text { Wind velocity }(\mathrm{m} / \mathrm{s}), \text { Area of } \\
\text { opening }\left(\mathrm{m}^{2}\right) \text {, schedule } \\
(\text { dimensionless })\end{array}$ \\
\hline Type of Nodes & Symbol & Property \\
\hline Air Node & O & $\begin{array}{l}\text { Connection with other room } \\
\text { surfaces via convective and } \\
\text { radiative elements }\end{array}$ \\
\hline Fxicrior Surface Node & $\mathrm{O}$ & $\begin{array}{l}\text { Connected via conduction to inner } \\
\text { layers and by convection and } \\
\text { radiation to outer layers. Exposed } \\
\text { to solar radiation. }\end{array}$ \\
\hline Interier Surface Node & O & $\begin{array}{l}\text { Connected to air node by } \\
\text { conduction and radiation. Intermal } \\
\text { nodes are connected by conduction } \\
\text { element }\end{array}$ \\
\hline Interior Node & $\mathrm{O}$ & $\begin{array}{c}\text { Connected by conduction elcment } \\
\text { to other interior nodes and surface } \\
\text { nodes }\end{array}$ \\
\hline Prescribed nodes & 0 & $\begin{array}{l}\text { Nodes that are not affected by all } \\
\text { other nodes and are only } \\
\text { dependent on weather conditions }\end{array}$ \\
\hline
\end{tabular}

Figure 2. Types and properties of nodes and elements

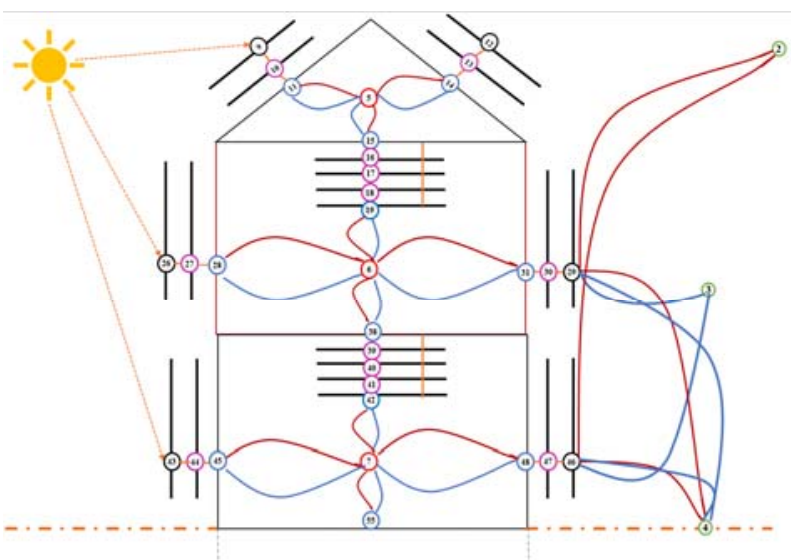

Figure 3.Nodal element mesh for MATLAB model

Using the standard finite element operation on the complete set of elements leads to the following differential algebraic equation (DAE) set:

$M(t) \frac{d T}{d t}+S(T ; t)=f(t)$

Where,

$M(t)=$ Mass matrix (heat storage capacity)

$\mathrm{S}(\mathrm{T}, \mathrm{t})=$ Stiffness matrix (heat exchange relationships)

$\mathrm{f}(\mathrm{t})=$ Load vector (thermal load on the nodes)

The load vector comprises of entering solar loads and internal gains from appliances and metabolic heat gain from occupants in the thermal zone. Solar heat absorption at a surface is calculated as

$\dot{Q}_{\text {sol, } i}=F_{\text {shad }, i} A_{i} \varepsilon_{i} \dot{q}_{\text {sol }, i}$

Where,

$\mathrm{F}_{\text {shad }, \mathrm{i}}=$ Shading coefficient for surface his (dimensionless)

$\mathrm{A}_{\mathrm{i}}=$ Area of exposed surface his $\left(\mathrm{m}^{2}\right)$

$\varepsilon_{\mathrm{i}}=$ Absorptivity of coating on surface his (dimensionless) $\dot{\mathrm{q}}_{\mathrm{sol}, \mathrm{i}}=$ solar insolation incident on surface his $\left(\mathrm{W} / \mathrm{m}^{2}\right)$

Solar radiation incident on the exposed surfaces like wall and roof are calculated by a subroutine which uses equations presented in Chapter 14, section 2 (2013 ASHRAE Handbook - Fundamentals (I-P Edition) Knovel, n.d.). Incident solar radiation per unit area $\left(\mathrm{q}_{\mathrm{sol}, \mathrm{i}}\right)$ is computed and returned to the main program where it is multiplied by the area and shading coefficient of the surface to obtain solar thermal loads. Figure 4 illustrates the process for the calculation of solar loads that contribute to the load vector $\mathrm{f}(\mathrm{t})$.

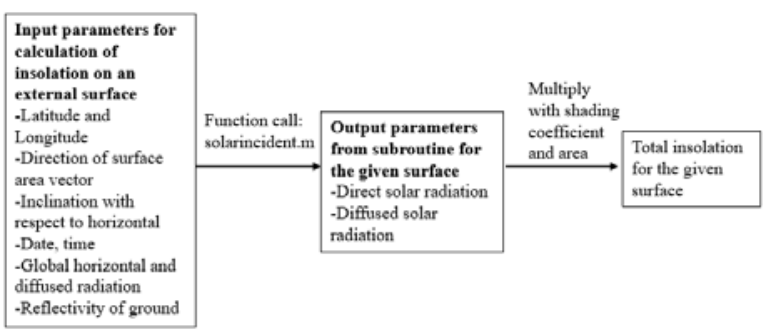

Figure 4 Computation of solar loads on each surface

Insolation falling on the windows makes its way inside the dwelling either by conduction through window material or is directly transmitted inside the zone where window is mounted. Directly transmitted radiation is absorbed partly by mass present inside the room like furniture/ground and partly by the air node. Transmission inside building as well as absorption of heat by window materials is governed by window properties which are mentioned in Table 1.

Air Flow Network and Basement Model: A "ventilationelement" is used to construct an airflow network between outside and inside and between internal zones. Single sided volumetric air flow rate through window openings is determined by equation 37 in Chapter 16 of ASHRAE fundamentals 2009;

$Q_{w}=C_{w} A_{\text {opening }} F_{\text {schedule }} V$

Where, $\mathrm{Q}_{\mathrm{w}}=$ Volumetric Flow rate driven by wind $\mathrm{C}_{\mathrm{w}}=$ Opening effectiveness (dimensionless)

$\mathrm{A}_{\text {opening }}=$ Opening area $\left(\mathrm{m}^{2}\right)$

$\mathrm{F}_{\text {schedule }}=$ Open area fraction (dimensionless)

$\mathrm{v}=$ Local wind speed $(\mathrm{m} / \mathrm{s})$

The window opening fraction is assumed to be governed by a simple but adequate regime, which is based on the assumption that a window is open $100 \%$ of its area in a condition that indoor air temperatures supersede ambient temperature. In practice this means that an occupant will open the window if bringing in outside air will lower the temperature in the zone. At a time when the available cooling capacity is sufficient to maintain a temperature that is lower than the outside temperature, the window is closed again.

Figure 5 (a) shows the dressed down version of the otherwise densely packed nodal model of basement and its interaction with other thermal zones as well as the ambient environment. Each node on the surface has an area equal to $1 / 3^{\text {rd }}$ of total skin area of the basement (wall) 
effectively sectioning the total wall area in three parts along its perimeter. Only the first wall section is connected to the ambient conditions via active soil mass. The other two sections are connected to an undisturbed constant temperature soil node at sufficient distance from the house. The soil node temperatures are calculated by running the simulation for 10 years, cycling through winter and summer conditions.

Each node along the path inside the soil is encased by a fictitious cuboid of active mass Figure 5 (b).

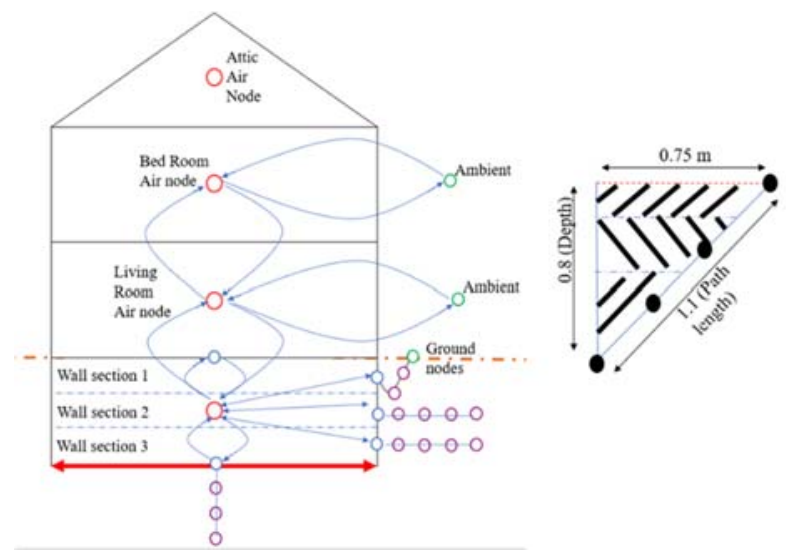

Figure 5 (a)Basement nodal model and (b)mass appropriation

HVAC and Moisture Balance: Each thermal zone has a window unit, that, when working on full capacity supplies conditioned air at $18^{\circ} \mathrm{C}$ with a humidity ratio of $0.008 \mathrm{~kg} / \mathrm{kg}$. The mass flow of air from the unit is constant during its operation and the average velocity of air in the thermal zone is $0.15 \mathrm{~m} / \mathrm{s}$. Sensible load calculations are performed in accordance with American National Standards Institute (ANSI) recognized ACCA's updated ANSI/ACCA 2 Manual J - 2016 (Residential Load Calculations). The summer design day temperature for Atlanta is $34^{\circ} \mathrm{C}$ according to Table $1 \mathrm{~A}$ of the manual and design indoor air temperature is $24^{\circ} \mathrm{C}$.

The underperformance of residential air conditioners may happen due to many reasons such as_undersized system, low air-flow, infiltration due to aged building and undercharged gas levels ("Monitored in-situ performance of residential air-conditioning systems / Discussion ProQuest," n.d.). To verify the effect of different levels of underperformance, four levels of efficiency ie, $100 \%$, $80 \%, 50 \%$ and $30 \%$ of (calculated) sensible load are simulated for all zones of the mentioned building prototypes and their variants where the air humidity ratio of deficient HVAC is fixed at $0.010 \mathrm{~kg} / \mathrm{kg}$.

A macro moisture balance based on net influx of moisture by ventilation, internal production from human activity, and the net removal of moisture by the HVAC system is modeled as;

$\frac{\mathrm{dm}_{\mathrm{w}, \mathrm{sys}}}{\mathrm{dt}}=\sum \dot{\mathrm{m}}_{\mathrm{w}, \text { in }}-\sum \dot{\mathrm{m}}_{\mathrm{w}, \text { out }}+m_{\text {gen }}$

Where,

$\frac{d m_{w, s y s}}{d t}=$ Change in total amount of moisture in the room $\sum \dot{\mathrm{m}}_{\mathrm{w}, \mathrm{in}}=$ mass flow rate of moisture (inflow) $(\mathrm{kg} / \mathrm{kg})$

$\sum \dot{\mathrm{m}}_{\mathrm{w}, \mathrm{out}}=$ mass flow rate of moisture (outflow) $(\mathrm{kg} / \mathrm{kg})$

$\mathrm{m}_{\text {gen }}=$ moisture generated through respiration of occupants ( $\mathrm{kg} /$ hour) fixed at $0.08 \mathrm{~kg} /$ hour-person

\section{Heat Indices and Post Processing}

The simulation models are deployed for all variants and HVAC deficiency levels for a period of six summer months in Atlanta ( $15^{\text {th }}$ April to $15^{\text {th }}$ October, 4392 hours). Hourly temperatures inside the living room are recorded and used in the calculation of the indices, introduced below.

Predicted Mean Vote: Predicted Mean Vote devised by Fanger is one of the most acceptable and extensively used indices for human thermal comfort and forms a basis of many standards like the International Standard Organization (ISO 7730), European Standard Organization and ASHRAE 55 (2013 ASHRAE Handbook - Fundamentals (I-P Edition) - Knovel, n.d.).

The PMV predicts the mean value of the votes of a large group of people on the ISO thermal sensation scale $(+3=$ hot; $+2=$ warm; $+1=$ slightly warm; $0=$ neutral; $-1=$ slightly cool; $-2=$ cool; $-3=$ cold).

Heat Stress Index: The HIS is based upon a comparison of the amount of sweat that must be evaporated $\left(E_{\text {req }}\right)$ to maintain thermal equilibrium, with the maximum amount of sweat that can be evaporated under the prevailing climatic conditions (maximum evaporative capacity) (health \& 2006, n.d.). The ratio of these two factors is the Heat Stress Index for given conditions.

The HIS as an index that is related to thermal strain, essentially in terms of body sweating, with values between 0 and 100. At HSI $=100$, the evaporation required is the maximum that can be achieved for the environmental conditions with given clothing and metabolic rate, and thus represents the upper limit of the prescriptive zone (see Table 2).

Apparent Temperature: Apparent temperature or Heat Index is the guiding marker used by federal agencies to warn residents about heat waves and the risk of heat stroke. It assesses the sultriness of environment using the work of (Rothfusz, Worth, National, \& 1990, n.d.).

Operative Temperature: Operative temperature is the simplest indicator of indoor thermal comfort and is easy to use to express the thermal experience of the occupant. It is the average of air and mean radiant temperature at low air velocities typically less than $0.2 \mathrm{~m} / \mathrm{s}$ (Kazkaz, Mechanics, \& 2013, n.d.; Nicol, Hacker, Spires, \& Davies, 2009).

Table 2 Reference values for Indices

\begin{tabular}{|c|c|c|}
\hline & $\begin{array}{l}\text { Reference } \\
\text { Value }\end{array}$ & Implication \\
\hline $\begin{array}{c}\text { Apparent } \\
\text { Temperature }\end{array}$ & 80 & Caution \\
\hline $\begin{array}{l}\text { Operative } \\
\text { Temperature }\end{array}$ & 25 & $\begin{array}{l}\text { recommended by ASHRAE @ } \\
\text { clo=1 met and vel }<0.2 \mathrm{~m} / \mathrm{s}\end{array}$ \\
\hline Heat Stress Index & 10 & Mild to moderate heat strain \\
\hline PMV & $>0.5$ & Slightly Warm \\
\hline
\end{tabular}

Post Processing: The post processing of heat stress indicators is done to accomplish three tasks, namely; 
- Compare types of constructions and their variants with respect to their responsiveness to ambient conditions.

- Compare building performance outcomes for HMY versus TMY

Table 3 Heat Indices and weights of physical parameters

\begin{tabular}{|c|c|c|}
\hline Index & Equations & Symbol and Units \\
\hline Operative Temperature & OT $=T_{a}+T_{r}$ & $\begin{array}{c}T_{a}=\text { air temperature }\left({ }^{\circ} \mathrm{C}\right), \\
T_{\mathrm{r}}=\text { mean radiant temperature }\left({ }^{\circ} \mathrm{C}\right)\end{array}$ \\
\hline $\begin{array}{l}\text { Apparent Temperature } \\
\text { (Heat Index HI) }\end{array}$ & $\begin{array}{l}\mathrm{HI}=-42.379+2.04901523 \mathrm{~T}+ \\
10.14333127 \mathrm{R}-0.22475541 \mathrm{R}-{ }^{-2} \\
6.83783 \times 10^{-3} \mathrm{~T}^{2}-5.481717 \times 10^{-2} \mathrm{R}^{2}+ \\
1.22874 \times 10^{-3} \mathrm{~T}^{2} \mathrm{R}+8.5282 \times 10^{-4} \mathrm{TR}^{2}- \\
1.99 \times 10-6 \mathrm{~T} 2 \mathrm{R}^{2}\end{array}$ & $\begin{array}{c}\mathrm{T}=\text { air temperature }\left({ }^{\circ} \mathrm{F}\right) \\
\mathrm{R}=\text { relative humidity (integer percentage) }\end{array}$ \\
\hline PMV & $\begin{array}{l}\mathrm{PMV}=3.155\left(0.303 e^{-0.114 M}+0.028\right) \mathrm{L} \\
\mathrm{L}=q_{\text {met, heat }}-f_{c l} h_{c}\left(T_{c{ }^{-}}-T_{a}\right)-f_{c l} h_{r}\left(T_{c l}{ }^{*}\right. \\
\left.\left.T_{r}\right)-156 W_{s k, r e q}-W_{a}\right)-0.42\left(q_{\text {metheat }}\right. \\
18.43)-0.00077 \mathrm{M}\left(93.2-T_{a}\right)- \\
2.78 \mathrm{M}\left(0.0365-W_{a}\right)\end{array}$ & $\begin{array}{c}T_{c l}=\text { average surface temperature of } \\
\text { clothed body }\left({ }^{\circ} \mathrm{F}\right) \\
f_{c l}=\text { ratio of clothed surface to DuBois } \\
\text { surface } \\
T_{a}=\text { air temperature }\left({ }^{\circ} \mathrm{F}\right) \\
h_{c}=\text { convection heat transfer coefficient } \\
\left.\text { (Btu/h } f t^{2}\right) \\
T_{r}=\text { mean radiant temperature }\left({ }^{\circ} \mathrm{F}\right) \\
h_{r}=\text { radiative heat transfer coefficient } \\
\left.\text { (Btu/h } f^{2}{ }^{\circ} \mathrm{F}\right) \\
W_{a}=\text { air humidity ratio } \\
W_{s k}=\text { saturated humidity ratio at skin } \\
\text { temperature }\end{array}$ \\
\hline HSI & $\begin{array}{c}\mathrm{HSI}=\left(E_{r e q} / E_{\max }\right) \times 100 \\
E_{\max }=K_{E} \mathrm{v} 0.6\left(42-P_{w}\right) \\
E_{r e q}=\mathrm{M}+\mathrm{R}+\mathrm{C} \\
\mathrm{R}=K_{r}\left(T_{r}-35\right), \mathrm{C}=K_{c} \mathrm{v} 0.6\left(T_{a}-35\right)\end{array}$ & $\begin{array}{c}T_{a}=\text { air temperature }\left({ }^{\circ} \mathrm{C}\right) \\
T_{r}=\text { mean radiant temperature }\left({ }^{\circ} \mathrm{C}\right) \\
\text { v=air velocity }(\mathrm{m} / \mathrm{s}) \\
P_{w}=\text { water vapor pressure of ambient air } \\
\text { (mmHg) } \\
\mathrm{M}=\text { metabolic rate }(\mathrm{W}) \\
\mathrm{R}=\text { radiant Heat exchange }(\mathrm{W}), \\
\mathrm{C}=\text { convective heat exchange }(\mathrm{W}), \\
K_{E}=27.1, K_{r}=12.8, K_{c}=13.6[\text { for summer } \\
\text { clothing of Shorts and T-shirt] }\end{array}$ \\
\hline
\end{tabular}

- Compare thermal indices and their sensitivity to indoor environment in different cases of HVAC deficiency.

The following parameters are defined to characterize the extremity of heat as well as sensitivity of indices to thermal environment;

Hours of exceedance- Each hourly value is compared with its reference (Table 2) to sum up the hours when it breaches its acceptable limit. Since the run time of simulation is congrient in all cases, exceedance represents the sensitivity of indices towards varying temperatures. Index Aggregation: A single value is needed to compactly represent the response of building for the whole summer period in a way that informs about the combination of the duration of stress and the extremity of the same. The following shows how this can be achieved for different measures.

$\mathrm{PMV}_{\mathrm{i}}=\left[\frac{\text { Index value for an hour }}{\text { Reference Value }}\right] \times\left\lfloor\frac{1}{n}\right\rfloor[$ Index for an hour $]$

$\mathrm{PMV}_{\text {simulation period }}=\mathrm{PMV}_{1+} \mathrm{PMV}_{2}+\ldots \ldots \ldots .+\mathrm{PMV}_{\mathrm{n}}$

Where, $\mathrm{n}=$ Total hours

\section{Results and Discussion}

\section{Sensitivity to Indoor Environment}

Figure 6 suggests that year 1980, 2007 and 2012 were exceptionally hot summers in Atlanta. When operative temperatures plots are seen in contrast with other measures, only a few years suggest to be as extreme. The problem of heat stress is compounded when houses are unshaded exposing a larger part of the building skin to solar irradiation. A large skin to volume ratio affects indoor thermal environment in two ways, by raising the air temperature as well as the MRT.

On one hand, the non-masonry construction resists the heat influx due to its insulation in the wall construction.
On the other hand, masonry construction materials not only conduct the heat fairly well but also have enough mass to absorb it during the day and release it in the night increasing the number of hours when the indoor environment is hot and uncomfortable. High thermal mass elongates the duration of heat spell thereby increasing the hours that an index is above its reference value.

Lower hours of exceedance for all indices in shaded and non-masonry constructions confirm the above explanation.

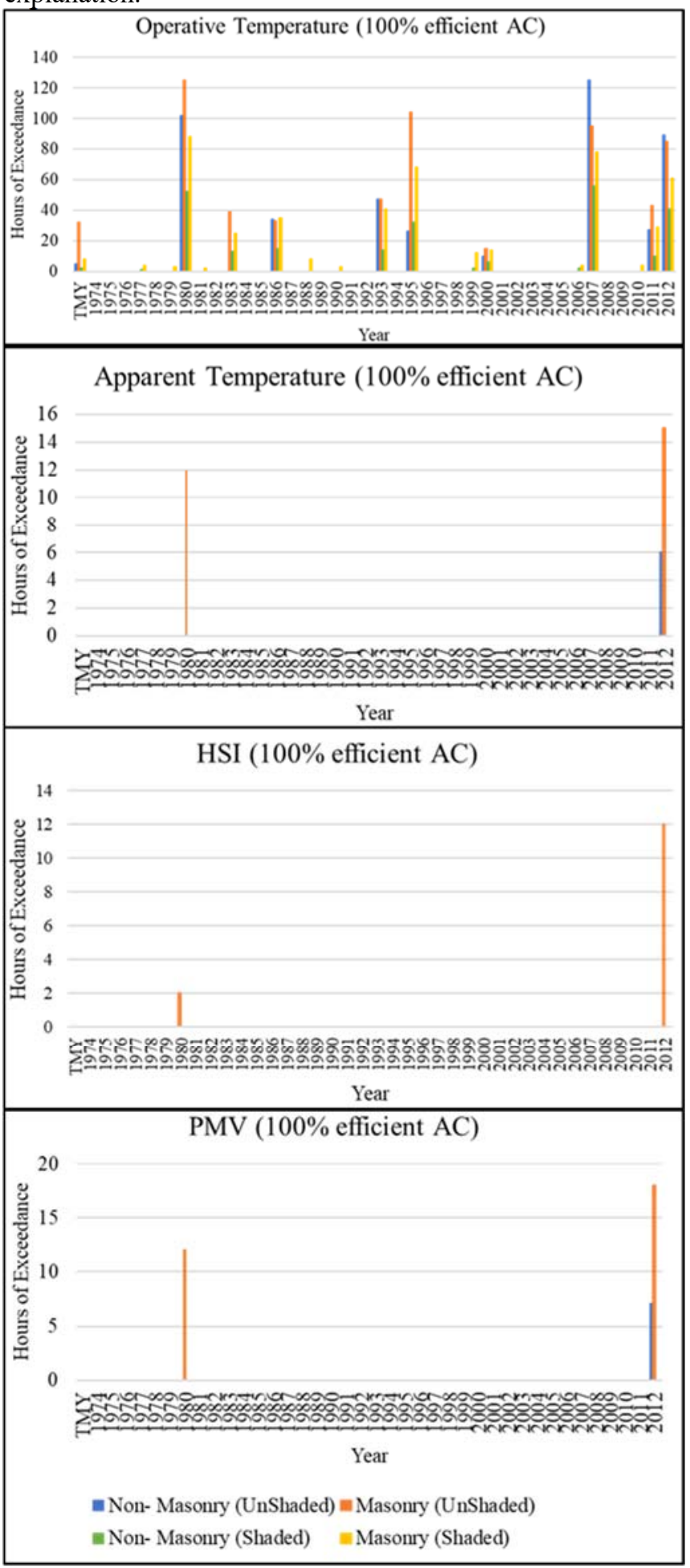

Figure 6 Hours of Exceedance at HVAC operating at design conditions 
Figure 7 reflects the effect that a deficient HVAC has on thermal comfort in a living space. It is observed that exceedance for HSI increases much lesser pace as compared to other measures indicative of the fact that it responds to only very high temperatures. It is noteworthy that shaded building variants at $80 \%$ of designed conditions perform virtually as well as their non-shaded counterparts at $100 \%$ efficiency.
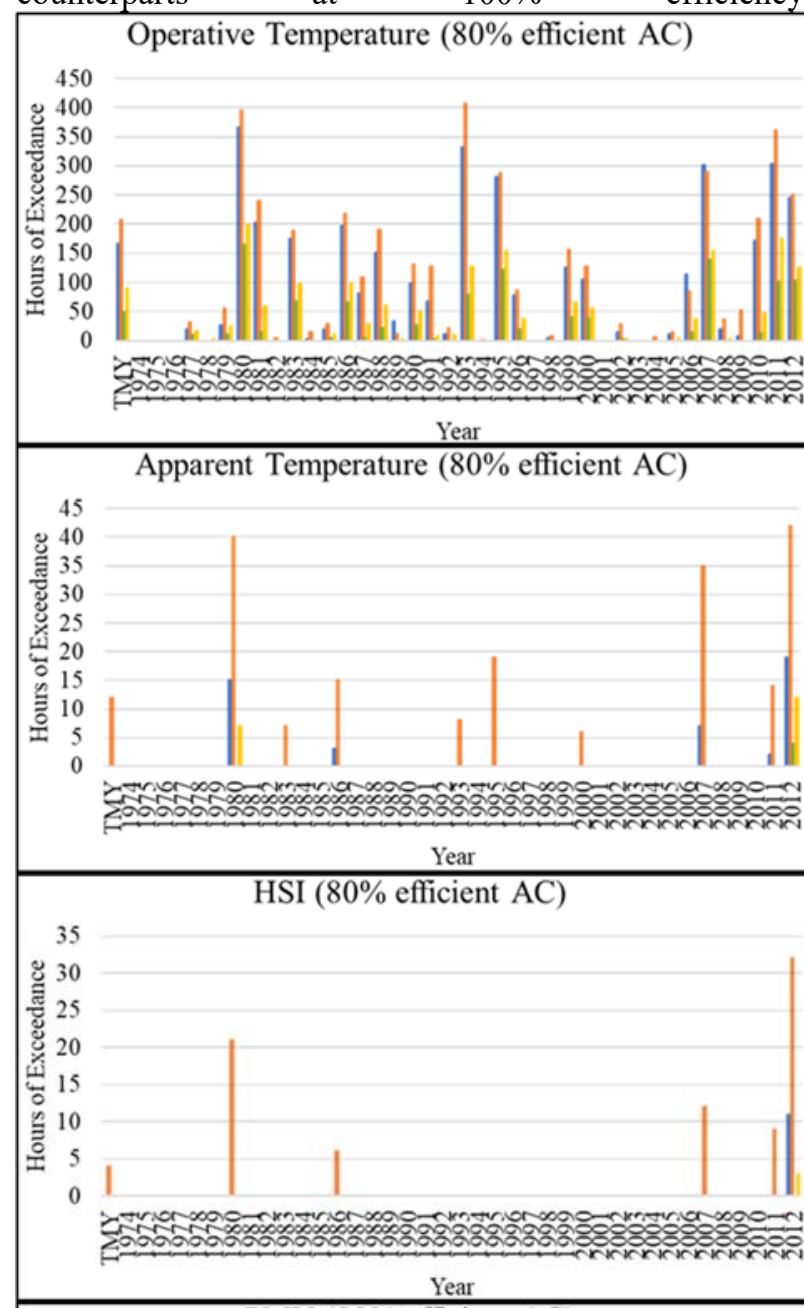

PMV $(80 \%$ efficient AC)

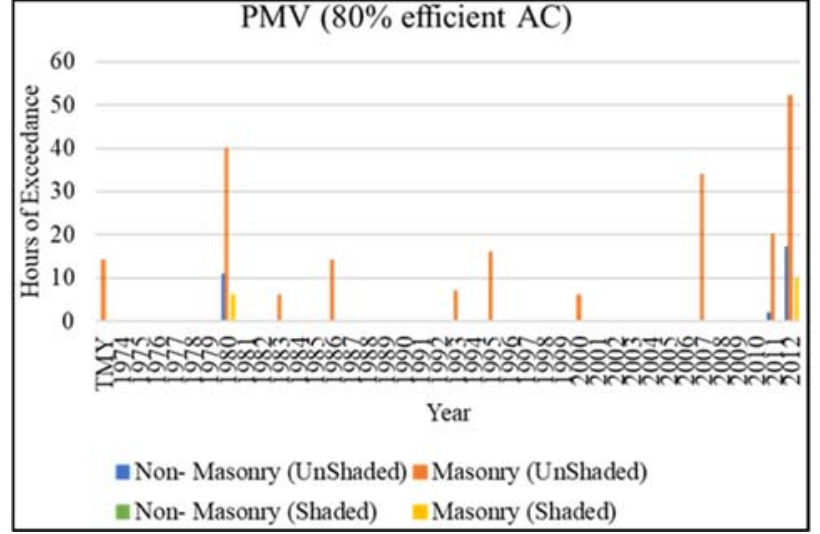

Figure 7 Hours of exceedance for HVAC operating at 80\% of designed conditions

Another observation is the stark difference between the uncomfortable hours depicted by TMY vs HMY in Figure 7. In year 2012, the HSI has up-to 30 hours of exceedance as compared to TMY with a mere 5 hours heat exposure further advocating the use of this framework for studies related to exposure to heat risk.

The heat strain on occupants of masonry non-shaded variants is almost twice that of the non-masonry homes and thrice that of shaded masonry structures. Note that these outcomes use a fairly conservative reference value, i.e. for mild heat strain. But there is proof that this level is hazardous for the vulnerable sections of society like people suffering from respiratory conditions, heart diseases or the elderly to name a few.

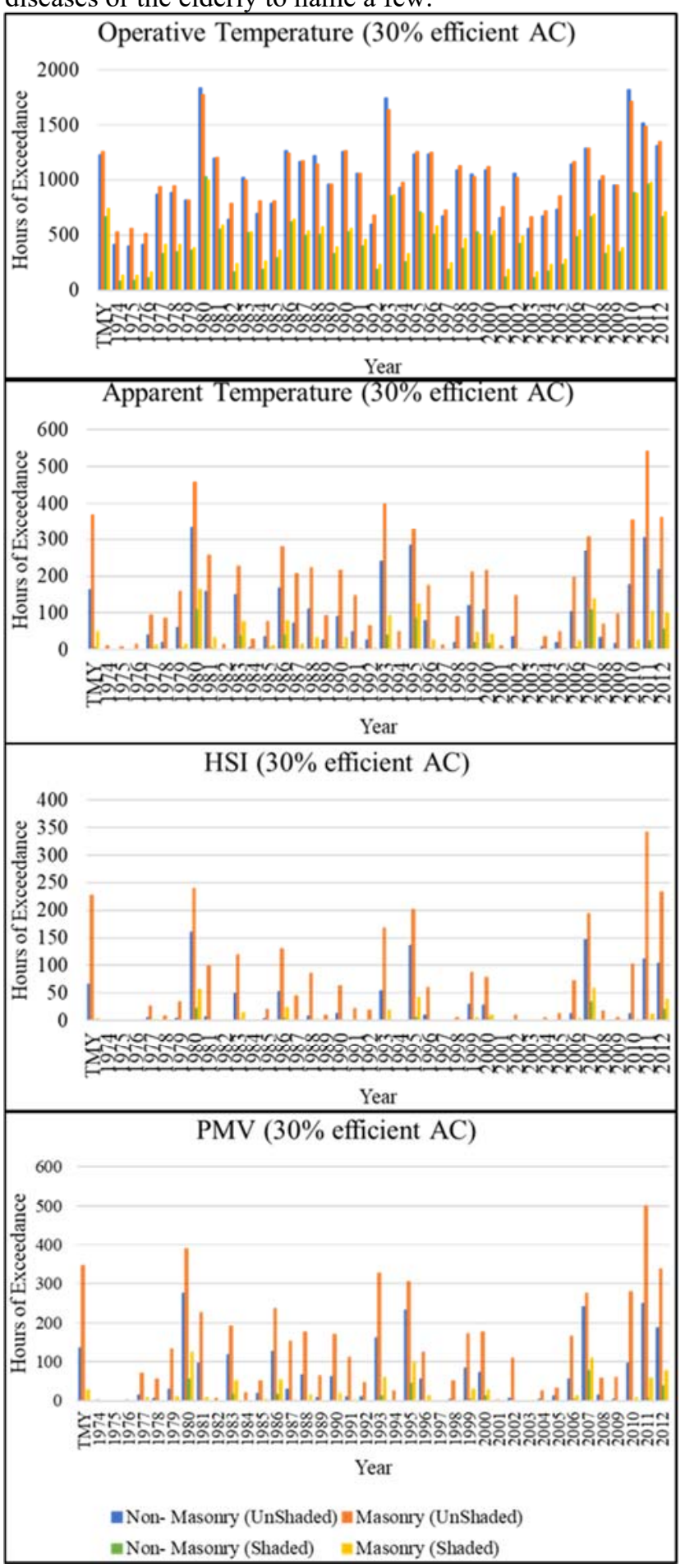

Figure 8 Hours of exceedance for HVAC operating at 30\% of designed conditions 
Figure 8 confirms that all indices advocate the effectiveness of non-masonry constructions to provide a better thermal environment as compared to its masonry counterparts in the hot and humid climate of Atlanta. In addition to construction, shading plays an important role in reducing heat stress for building occupants.

From the above observations, it is safe to say that operative temperature shows the highest sensitivity towards thermal discomfort and HSI is the best representative of heat stress, all other indices fall somewhere in between

\section{Assessment of Severity of Hot Spell}

The severity of extreme indoor temperatures over a certain period can only be assessed when the chosen discomfort or health impact measure not only considers exceedance hours of an acceptable reference value but also the actual levels during those exceedance hours. It is customary to choose one specific value as an aggregated value to express severity in literature.

Aggregated values are also helpful to study the relevance of using TMY as compared to HMY when mechanical systems can't provide the required cooling. The figures in this section of results shows the spread of aggregated indices for 38 HMY's (1974-2012) in the form of histogram and position of aggregated index for TMY in the same graph for HVAC efficiencies at $80 \%, 50 \%$ and $30 \%$ efficiency.

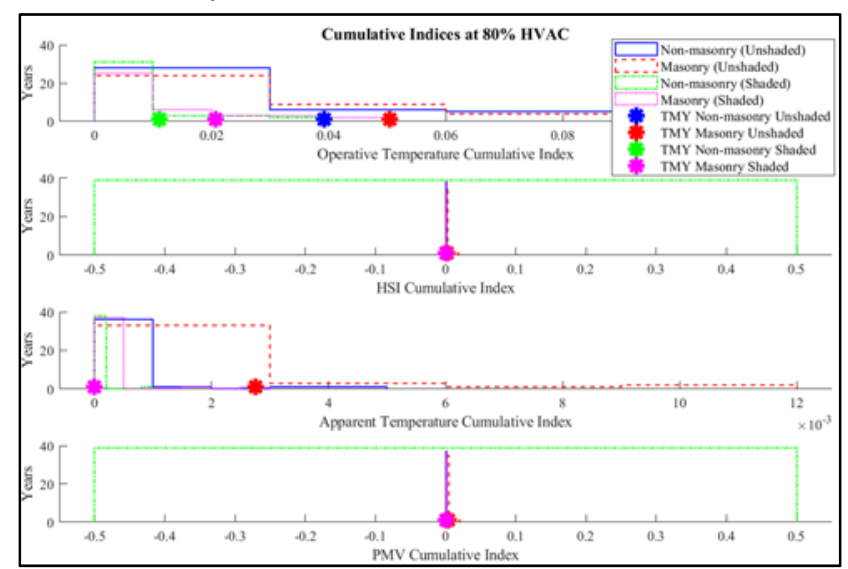

Figure 9 Cumulative Indices at $80 \%$ of designed HVAC capacity

When the HVAC is operating near designed conditions, ie, $80 \%$ in Figure 9, aggregated PMV has least affect on it as all the variants for all HMY as well as TMY hover around the mean of 0 .

However, from the apparent as well as operative temperature plots it is evident that TMY takes a fairly conservative estimate of weather severity. In nearly all the cases, TMY aggregated index fall ahead of mean HMY bins but remains far from the extreme values suggesting that it would be a gross error to utilize it for heat risk studies.

As the simulation is done with deteriorating values of HVAC efficiency, it becomes discernible that shading on exterior surfaces can have a huge impact on the temperatures inside the living spaces making them comfortable even if air conditioning is not available at designed capacity.

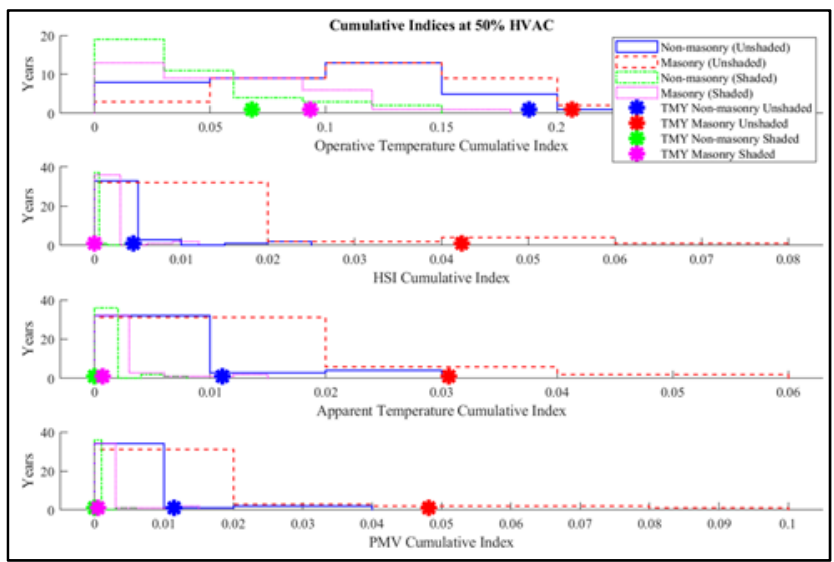

Figure 10 Cumulative Indices at 50\% of designed HVAC capacity

Cumulative indices for all indices fall consistently on the lower end of spectrum when the buildings are shaded. HSI for shaded variants is close to zero for almost all HMY's indicating that inhabitants of shaded buildings will experience the least hours of heat stress as compared to other variants.

It may also be observed that for cumulative indices except operative temperature, there is a huge gap between masonry and non masonry structures.

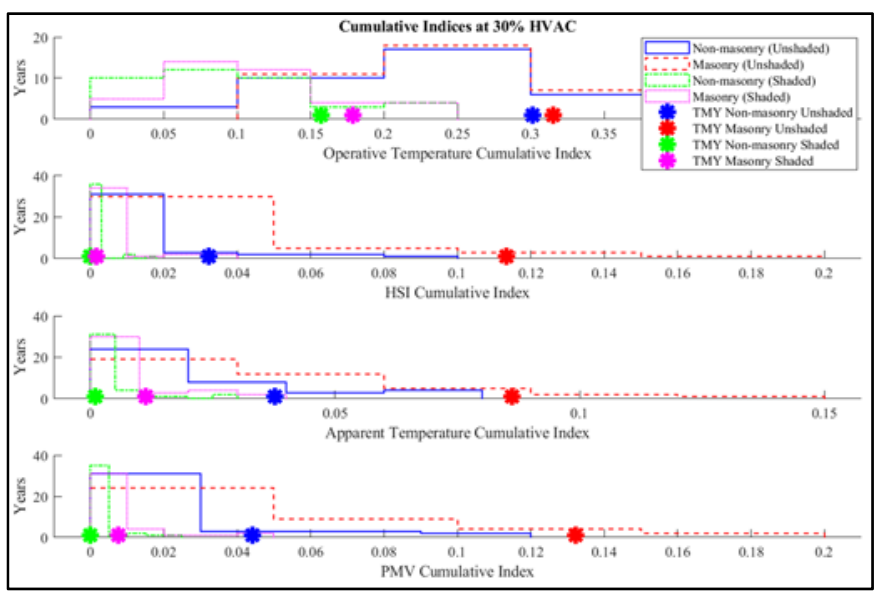

Figure 11 Cumulative Indices at 30\% of designed HVAC capacity

For air conditioner with only $30 \%$ of required cooling capacity, the shaded variants start to draw close together irrespective of construction materials. However, there is always a large gap, as much as three fold, between the unshaded masonry structure vs non-masonry structure. Cumulative index for TMY in the unshaded cases always lies on the higher end of "mean" aggregated measures bin but quite far from the extreme values.

\section{Conclusion}

1. Aggregated TMY indices steadily follow the mean of aggregated HMY's (Figure 9) which is consistent with its purpose. However, it fails to evaluate the heat risk in an extreme year (in this case 1980 or 2012). 
2. As noticed in Figure 6,7 and 8, masonry structures, which constitute the oldest building stock in Atlanta prove to be not as effective as relatively newer nonmasonry buildings in terms of providing better thermal performance.

3. The sensitivity of an index depends on the indoor temperatures and in some case relative humidity and the weights that are utilized in computing the index. For example, Operative temperature depends only on air and mean radiant temperature making it highly sensitive to temperature changes (refer Table 3 ).

However, for same temperature changes, HSI has subtle variations as it also depends on clothing, air velocity and water vapor pressure of ambient air. Due to the variability in the extent of thermal environment quality representation, it would be interesting to examine the computed indices and scrutinize them with public health records from simulated years to assess their utility and rankings.

4. Shading can have a dramatic impact in cities like Atlanta with high insolations in reducing thermal strain inside the buildings.

From the above discussion, it may be inferred that low cost energy efficiency options like efficient windows, shading devices and trees aide in lowering indoor temperatures and hence reducing overheating risk of vintage buildings. For decisions pertaining to community wide investments, the older building stock consisting largely of vintage masonry buildings needs to phase-out and be replaced to avoid the risk of heat stress in marginalized sections of society.

\section{References}

2013 ASHRAE Handbook - Fundamentals (I-P Edition) Knovel. (n.d.). Retrieved from https://app.knovel.com/web/toc.v/cid:kpASHRAE B2/viewerType:toc//root_slug:2013-ashraehandbook

Augenbroe, G., Brown, J., Heo, Y., Kim, S., Z. L.-P. of, \& 2008, undefined. (n.d.). Lessons from an advanced building simulation course. IbpsaUsa.Org. Retrieved from http://www.ibpsausa.org/index.php/ibpusa/article/view/262

Beshir, M., \& Ramsey, J. D. (1988). Heat stress indices: A review paper. International Journal of Industrial Ergonomics, $3(2)$, 89-102. https://doi.org/10.1016/0169-8141(88)90012-1

CIBSE Guide C - Reference Data - Georgia Tech Library. (n.d.).

Epstein, Y., \& Moran, D. S. (2006). Thermal Comfort and the Heat Stress Indices. Industrial Health, 44(3), 388-398. https://doi.org/10.2486/indhealth.44.388

Heat stress standard ISO 7243 and its global application. Jstage.Jst.Go.Jp. Retrieved from https://www.jstage.jst.go.jp/article/indhealth/44/3/ 44_3_368/_article/-char/ja/
International Council for Research and Innovation in Building and Construction., A., \& Akbari, H. (1977). Energy and buildings. Energy and Buildings (Vol. 25). Elsevier Sequoia S.A.

Akbari, H., et al., Peak power and cooling energy savings of shade trees. Energy and Buildings, 1997 \&offset $=0$

Kazkaz, M., Mechanics, M. P.-E., \& 2013, undefined. (n.d.). Operative temperature and globe temperature. Engineeringmechanics.Cz. Retrieved from

http://www.engineeringmechanics.cz/pdf/20_3_31 9.pdf

Lim, H., \& Zhai, Z. J. (2017). Review on stochastic modeling methods for building stock energy prediction. Building Simulation, 10(5), 607-624. https://doi.org/10.1007/s12273-017-0383-y

Masoud, S., Sameni, T., Gaterell, M., Montazami, A., \& Ahmed, A. (2015). Overheating investigation in UK social housing flats built to the Passivhaus standard.

https://doi.org/10.1016/j.buildenv.2015.03.030

Monitored in-situ performance of residential airconditioning systems / Discussion - ProQuest. (n.d.). Retrieved from https://search-proquestcom.prx.library.gatech.edu/docview/192579263?rf r_id $=$ info $\% 3$ Axri $\% 2$ Fsid $\% 3$ Aprimo

Nicol, J. F., Hacker, J., Spires, B., \& Davies, H. (2009). Suggestion for new approach to overheating diagnostics. Building Research \& Information, 37(4), 348-357. https://doi.org/10.1080/09613210902904981

Residential Prototype Building Models | Building Energy Codes Program. (n.d.). Retrieved January 31, 2019, from

https://www.energycodes.gov/development/reside ntial/iecc_models/

Rothfusz, L., Worth, N. H.-F., National, T., \& 1990, undefined. (n.d.). The heat index equation (or, more than you ever wanted to know about heat index). 204.227.127.200. Retrieved from http://204.227.127.200/images/oun/wxsafety/sum merwx/heatindex.pdf

Shirazi, A., Environment, B. A.-B. and, \& 2018, undefined. (n.d.). Embodied life cycle assessment comparison of single family residential houses considering the 1970s transition in construction industry: Atlanta case study. Elsevier. Retrieved from

https:/www.sciencedirect.com/science/article/pii/ S0360132318302816

Zhao, F., Lee, S. H., \& Augenbroe, G. (2016). Reconstructing building stock to replicate energy consumption data. Energy and Buildings, 117, 301312. https://doi.org/10.1016/j.enbuild.2015.10.001 
